\title{
Estimates of lactation curve parameters for Bonsmara and Nguni cattle using the weigh-suckle-weigh technique
}

\author{
A. Maiwashe ${ }^{1 \#}$, N.B. Nengovhela ${ }^{1}$, K.A. Nephawe ${ }^{2}$, J. Sebei ${ }^{2}$, T. Netshilema ${ }^{1}$, \\ H.D. Mashaba ${ }^{1}$, L. Nesengani ${ }^{1,3}$ \& D. Norris ${ }^{1}$ \\ ${ }^{1}$ ARC-Animal Production Institute, Animal Breeding and Genetics Programme, Private Bag X2, Irene, 0062 \\ ${ }^{2}$ Limpopo Department of Agriculture, 69 Biccard Street, Private Bag X9487, Polokwane, 0700 \\ ${ }^{3}$ University of Limpopo, Turfloop Campus, Private Bag X1106, Sovenga, 0727
}

(Received 29 September 2012; Accepted 16 February 2013; First published online 30 May 2013)

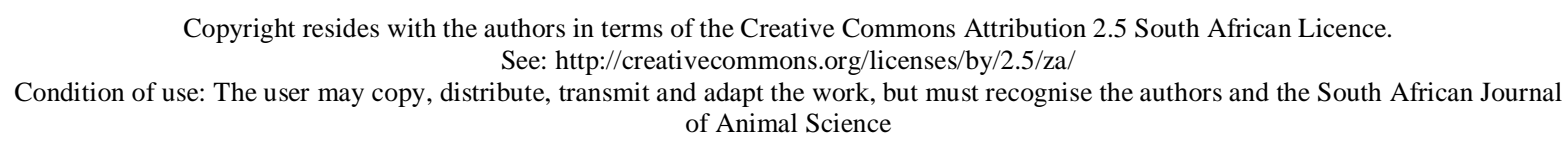

Copyright resides with the authors in terms of the Creative Commons Attribution 2.5 South African Licence.

See: http://creativecommons.org/licenses/by/2.5/za/

Condition of use: The user may copy, distribute, transmit and adapt the work, but must recognise the authors and the South African Journal of Animal Science

\begin{abstract}
Milk production accounts for about $60 \%$ of the variation in weaning weight and is therefore considered an economically important trait in beef production. However, milk production data is not routinely available in beef improvement programmes and therefore weaning weight is used as a proxy for milk production. Despite the importance of milk production in beef cattle, little research has been done to evaluate the milk production potential of South African indigenous beef cattle. The objective of this study was to estimate average lactation curve parameters for the South African Bonsmara and Nguni cattle. Milk yield was estimated using the weigh-suckle-weigh technique. Lactation curves were modelled using a nonlinear form of the incomplete gamma function (Wood function): $\mathrm{Y}_{\mathrm{t}}=\mathrm{at}^{\mathrm{b}} \exp ^{\mathrm{ct}}$. Estimates of the a, b and c parameters were $4.095 \pm 0.808,0.274 \pm 0.063$ and $0.005 \pm 0.001$ for the Bonsmara, respectively. Corresponding estimates for the Nguni were $1.869 \pm 1.527,0.451 \pm 0.242$ and $0.008 \pm 0.003$. Peak lactation time was estimated to be 59 days in Bonsmara and 54 days in Nguni. Estimates of peak yields were $10 \mathrm{~kg}$ and $7 \mathrm{~kg}$ for the Bonsmara and Nguni, respectively. Estimates of daily milk yield obtained in the current study provide useful baseline information for more accurate modelling of South African beef production systems.
\end{abstract}

Keywords: Beef cattle, milk production, subtropics

\#Corresponding author: norman@arc.agric.za

\section{Introduction}

Milk production is a trait of major economic importance in beef cattle due to its influence on calf preweaning growth (Clutter \& Nielsen, 1987). As a result, selection for maternal ability or milk production is practiced routinely in most beef improvement programmes globally. However, selection for milk production to increase weaning weight should not be viewed in isolation. It is important that selection for milk production take cognizance of the fact that increased milk production affects feed costs, rebreeding rates and replacement costs (Bourdon, 1998). For example, high milk producing cows require more feed than low milk producing cows (NRC, 2002). Montaño-Bermudez et al. (1990) reported a high positive correlation between milk production and maintenance requirements. Since feed resources are often limited under range conditions it is important that the cow's milk production potential is matched with the available feed resources. Cows use their body reserves to meet requirements for milk production when feed is limited with the consequence that the chance for re-breeding is diminished (Boggs et al., 1980). Brown \& Brown (2002) 
emphasized the importance of matching animal genotype to the environment. Jenkins \& Ferrell (1992) studied milk production potential of nine beef cattle breeds under different nutritional regimes. They found that both breed and energy intake level significantly influenced milk production.

Several studies have been conducted in beef cattle to evaluate milk production potential (e.g. Williams et al., 1978; Beal et al., 1990; Jenkins \& Ferrell, 1992). These studies were conducted using mainly European breeds raised under temperate environments except in few cases (e.g. Chabo et al., 2003). There is thus paucity of reliable estimates of milk production especially for breeds that are indigenous to Africa. The general lack of information on milk production makes it difficult to properly evaluate South African beef production systems. MacNeil \& Matjuda (2007) used maternal breeding values for weaning weight to estimate milk production for the Afrikaner, Bonsmara and Nguni cows. The objective of the current study was to estimate average lactation curve parameters for Bonsmara and Nguni cattle using estimates of milk yield obtained by the weigh-suckle-weigh technique. The weigh-suckle-weigh technique has been used extensively to obtain reliable estimates of milk production in beef cattle (Williams et al., 1978; Meyer et al., 1994; Lee \& Pollak, 2002; MacNeil \& Mott, 2006) and sheep (Benson et al., 1999; Ünal et al., 2007).

\section{Materials \& Methods}

Estimated milk yield records obtained from Bonsmara $(n=42)$ and Nguni $(n=16)$ cow-calf pairs were considered in the current study. A total of 715 observations were available for the analyses. The data were collected at the Mara Research Station in the Limpopo Province of South Africa during a 7-months period. Mara Research Station is located about $54 \mathrm{~km}$ west of Makhado $\left(23^{\circ} 05^{\prime} \mathrm{S}, 29^{\circ} 25^{\prime} \mathrm{E}\right)$ in the arid sweet bushveld area. The mean annual rainfall is $452 \mathrm{~mm}$ and the mean daily maximum temperature varies from 23 ${ }^{\circ} \mathrm{C}$ in June to $30^{\circ} \mathrm{C}$ in January. For the duration of the experiment cows were kept strictly under an extensive production environment, feeding solely on natural pasture without supplementary feeding. Veld condition of grazing camps was monitored and rotation was done based on the amount of forage available.

Milk yield was determined using the weigh-suckle-weigh technique (Totusek et al., 1973; Williams et al., 1978; Meyer et al., 1994; Lee \& Pollak, 2002; MacNeil \& Mott, 2006). Estimates of milk yield were obtained bi-weekly resulting in cows averaging 12 milk observations per lactation with a range of 8 to 15 . MacNeil \& Mott (2006) used four estimates of milk yield in a study to determine the correlation between milk yield and maternal genetic effect for weaning weight. More frequent estimates of milk yield per lactation were considered appropriate given that the interest in the current study was in characterising the lactation curve.

The weigh-suckle-weigh technique was carried out as follows. Cows and calves were separated at 15:00 for about 3 hours and re-united at 18:00 for about 30 minutes to allow the calves to suckle until the cows were milked out. Then, calves were separated from cows at 18:30. The following morning at 6:00 calves were weighed before they were re-united with their dams. Calves were allowed to suckle for about 30 minutes and re-weighed immediately. A positive weight difference between the weight of the calf before and after suckling was taken as an estimate of 12-hour milk yield. The 12-hour milk yield was adjusted to 24-h following Brown et al. (1996) i.e. [(milk yield / 12) x 24].

Individual cow daily milk yield was modelled using a non-linear function proposed by Wood (1967):

$$
\mathbf{y}_{\mathbf{t}}=\mathbf{a t}^{\mathbf{b}}(\exp )^{-\mathrm{ct}}
$$

where $y_{t}$ is 24-hour milk yield for a specific cow at the $t^{\text {th }}$ day of lactation, $\mathbf{a}$ is the level of initial yield, $b$ is the parameter associated with increase rate of yield during the inclining phase until peak time, $\mathbf{c}$ is the rate of decline after peak, $t$ is the time in days of lactation and exp is the base of the natural logarithm. The curve parameters were estimated using the NLIN Procedure of SAS (SAS, 2012).

\section{Results and Discussion}

Summary statistics for estimated milk yield for Bonsmara and Nguni cows are presented in Table 1. Bonsmara cows produced about $2.5 \mathrm{~kg} / \mathrm{d}$ more milk than Nguni cows. The mean milk yield in the Nguni was comparable to results by Brown \& Brown (2002) who reported mean daily milk production of $6.65 \mathrm{~kg} / \mathrm{d}$ and $6.13 \mathrm{~kg} / \mathrm{d}$ for Angus and Brahman cows, respectively. Wang et al. (2009) reported an average daily milk yield of $7.56 \mathrm{~kg} / \mathrm{d}$ on Brangus cows bred to six sire breeds. Nguni cows expressed slightly more variation in 
milk production compared to the Bonsmara. Meyer et al. (1994) reported CV of $44 \%$ and $39 \%$ for a single estimate of milk yield for the Hereford and Wokalup breeds, respectively.

Table 1 Summary statistics for estimated milk yield for Bonsmara and Nguni cows

\begin{tabular}{ccccc}
\hline Breed & $\mathrm{N}$ & Mean $(\mathrm{kg} / \mathrm{d})$ & STD & CV (\%) \\
\hline Bonsmara & 558 & 8.50 & 3.93 & 46.24 \\
Nguni & 157 & 6.00 & 3.07 & 51.24
\end{tabular}

N: number of weigh-suckle-weigh records; STD: standard deviation; CV: coefficient of variation.

The estimates of lactation curve parameters for Bonsmara and Nguni cattle are shown in Table 2. The estimate for the $a$ parameter of $4.095 \mathrm{~kg}$ indicate that initial milk yield tended to be higher in Bonsmara than the corresponding estimate for Nguni of $1.869 \mathrm{~kg}$. The rate of incline until peak yield tended to be higher in the Nguni than Bonsmara cattle. The decline in milk yield from peak time until weaning tended to be higher in Nguni than in Bonsmara.

Table 2 Estimates of lactation curve parameters in the Bonsmara and Nguni cattle

\begin{tabular}{lccc}
\hline \multirow{2}{*}{ Breed } & \multicolumn{3}{c}{ Parameter estimate \pm SE } \\
\cline { 2 - 4 } & $\mathrm{a}$ & $\mathrm{b}$ & $\mathrm{c}$ \\
\hline Bonsmara & $4.095 \pm 0.808^{*}$ & $0.274 \pm 0.063^{*}$ & $0.005 \pm 0.001^{*}$ \\
Nguni & $1.869 \pm 1.527$ & $0.451 \pm 0.242$ & $0.008 \pm 0.003^{*}$ \\
\hline
\end{tabular}

${ }^{*}$ Indicate that the parameter estimate is significantly different from zero at $P<0.05$.



Figure 1 Predicted lactation curve for the South African Bonsmara and Nguni cattle based on the Wood function. 
The parameters estimates shown in Table 2 were used to predict daily milk yield from calving to weaning (Figure 1). Milk yield tended to be more persistent in Bonsmara compared to the Nguni. The peak time occurred earlier in Nguni than in Bonsmara (i.e. 56 days vs. 59 days). In a comprehensive study involving nine beef cattle breeds, Jenkins \& Ferrell (1992) observed breed differences in peak time with a range of 62 to 77 days.

In the current study, peak milk yield was estimated to be $10 \mathrm{~kg} / \mathrm{d}$ and $7 \mathrm{~kg} / \mathrm{d}$ in the Bonsmara and Nguni, respectively. The estimated peak yield for the Bonsmara was within the range of $8.5 \mathrm{~kg} / \mathrm{d}$ to $11.9 \mathrm{~kg} / \mathrm{d}$ reported by Jenkins \& Ferrell (1992). The comparison of estimates from the current study should be made cautiously since breed by nutrition interaction could sometimes be sizeable (Brown \& Brown, 2002).

\section{Conclusions}

Bonsmara cows tended to produce more milk than Nguni cows. Lactation curves derived in the current study should provide useful baseline information for future genetic research such as assessment of the utility of maternal breeding value for weaning weight as an indicator trait for milk production in beef cattle. The focus in the current study was on modelling the average lactation curve for each breed. Future research should focus on modelling of lactation curves for individual animals to aid in the genetic evaluation of beef cows.

\section{Acknowledgement}

This research was jointly funded by the Agricultural Research Council, Limpopo Department of Agriculture, Red Meat Research and Development of South Africa (RMRD-SA) and Technology and Human Resources for Industry Programme (THRIP) of the Department of Trade and Industry (DTI). Technical assistance from the animal attendants at the Mara Research Station is greatly appreciated.

\section{References}

Beal, W.E., Notter, D.R. \& Akers, R.M., 1990. Techniques for estimation of milk yield in beef cows and relationships of milk yield to calf weight gain and postpartum reproduction. J. Anim. Sci. 68, 937-943.

Benson, M.E., Henry, M.J. \& Cardellino, R.A., 1999. Comparison of weigh-suckle-weigh and machine milking for measuring ewe milk production. J. Anim. Sci. 77, 2330-2335.

Boggs, D.L., Smith, E.G., Schalles, R.R., Brent, B.E., Corah, L.R. \& Pruitt, J.R., 1980. Effects of milk and forage intake on calf performance. J. Anim. Sci. 51, 550-523.

Bourdon, R.M., 1998. Shortcomings of current genetic evaluation systems. J. Anim. Sci. 76, 2308-2323.

Brown, M.A. \& Brown Jr., A. H., 2002. Relationship of milk yield and quality to preweaning gain of calves from Angus, Brahman and reciprocal-cross cows on different forage systems. J. Anim. Sci. 80, 2522-2527.

Brown, M.A., Brown Jr., A.H., Jackson, W.G. \& Miesner, J.R., 1996. Milk production in Brahman, Angus, and reciprocal-cross cows grazing common bermudagrass endophyte infected tall fescue. J. Anim. Sci. 74, 2058-2066.

Chabo, R.G., Koka, D.C. \& Oageng, T., 2003. Milk yield during the first four months of lactation and cow productivity of Brahman and Tuli beef cattle in South-East Botswana. J. Agric. Rural Dev. Trop. Subtrop. 104, 65-70.

Clutter, A.C. \& Nielsen, M.K., 1987. Effect of level of beef cow milk production on pre- and post-weaning calf growth. J. Anim. Sci. 64, 1313-1322.

Jenkins, T.G. \& Ferrell, C.L., 1992. Lactation characteristics of nine breeds of cattle fed various quantities of dietary energy. J. Anim. Sci. 70, 1652-1660.

Lee, C. \& Pollak, E.J., 2002. Genetic antagonism between body weight and milk production in beef cattle. J. Anim. Sci. 80, 316-321.

MacNeil, M.D. \& Mott, T.B., 2006. Genetic analysis of gain from birth to weaning, milk production and under conformation in Line 1 Hereford cattle. J. Anim. Sci. 84, 1639-1645.

MacNeil, M.D. \& Matjuda, L.E., 2007. Breeding objectives for Angus and Charolais specialized sire lines for use in the emerging sector of South African beef production. S. Afr. J. Anim. Sci. 37, 1-10.

Meyer, K., Carrick, M.J. \& Donnelly, B.J.P., 1994. Genetic parameters for milk production of Australian beef cows and weaning weight of their calves. J. Anim. Sci. 72, 1155-1165. 
Montaño-Bermudez, M., Nielsen, M.K. \& Deutscher, G.H., 1990. Energy requirements for maintenance of crossbred beef cattle with different genetic potential for milk. J. Anim. Sci. 68, 2279-2288.

NRC, 2000. Nutrient Requirements of Beef Cattle. National Academy Press, Washington, D.C., USA.

SAS Institute Inc. 2012. SAS 9.3 TS Level 1M1, WS32_7PRO Platform. Cary, N.C., USA.

Totusek, R., Arnett, D.W., Holland, G.L. \& Whiteman, J.V., 1973. Relation of estimation method, sampling interval, and milk composition to milk yield of beef cows and calf gain. J. Anim. Sci. 37, 153-158.

Ünal, N., Yakan, A., Koçak, S., Erol, H. \& Uğurlu, M., 2007. The effect of some factors on milk suckled by lambs. Biotech. Anim. Husb. 23, 145-152.

Wang, X.Z., Brown, M.A., F.Q., Gao, F.Q., Wu, J.P., Lalrnan, D.L. \& Liu, W.J., 2009. Relationship of milk production of beef cows to post-weaining gain of calves. The Prof. Anim. Sci. 25, 266-272.

Williams, J.H., Anderson, D.C. \& Kress, D.D., 1978. Milk production in Hereford cattle. I. Effects of separation interval on weigh-suckle-weigh milk production estimates. J. Anim. Sci. 49, 1438-1442.

Wood, P.D.P., 1967. Algebraic model of the lactation curve in cattle. Nature 216, 164-165. 